\title{
LIBRARIAN INTERPERSONAL COMMUNICATION IN IMPROVING SERVICE QUALITY AT THE SYEKH YUSUF LIBRARY UIN ALAUDDIN MAKASSAR
}

\author{
Fitriani $^{1}$ \\ Iskandar ${ }^{2}$ \\ Muhammad Yaumi ${ }^{3}$ \\ La Ode Ismail Ahmad ${ }^{4}$ \\ Andi Ibrahim 5 \\ Postgraduated program of UIN Alauddin Makassar ${ }^{1}$ \\ Alauddin StateIslamic University of Makassar ${ }^{2,3,4,5}$ \\ fitriani.u2@uin-alauddin.ac.id ${ }^{1}$
}

\begin{abstract}
This study aims to describe the interpersonal communication skills of librarians in building good relationships with users. The type of research used is qualitative with a descriptive approach. The method used is a methodological and scientific approach. The data is obtained using interview, observation and documentation guidelines. The data analysis is using data reduction, data display, and verification. The results showed that basically, the interpersonal communication of librarians in serving the users was quite good. However, the attitude of respect, empathy, audible, celebratory and humble shown by the Librarian towards the users is still less prominent and does not have clear standards. Thus librarians become less proactive in serving users.
\end{abstract}

Keywords: Librarian Interpersonal Communication; Service Quality

\section{BACKGROUND}

Interpersonal communication is an essential thing and must be owned by a librarian in interacting with users. Libraries are an organization that aims to collect various collections of library materials that are then served to users for use. So automatically, service activities are the center of library activities. The quality of library services is also greatly influenced by librarians' quality as executors in building good relationships with users. This relationship depends on good and effective interpersonal communication skills so that librarians can know how to deliver messages and receive messages, being a good listener, being an effective listener, being a pleasant person, and combining verbal and non-verbal communication when serving visitors. For all forms of service in the library, success can not be measured by only providing information. Still, The positive and negative effects of interaction between users and librarians are also the key to establishing good relations between users and librarians. Facts that exist from experience and observation, it appears that the implementation of library services that have been taking place in Indonesia, especially in some areas, has not been fully oriented to library visitors and still has a shallow quality of service. This phenomenon happened because the Librarian still has not realized the job optimally. For example, the service at the circulation desk that most visitors meet when first enter the library room, the Librarian is still indifferent and reluctant to greet even if only by smiling at the user. It is what ultimately forms a negative image. 
Meanwhile, user satisfaction is a measure of whether or not a service is good. In the library, many tasks must be done by the Librarian in terms of serving the users. Therefore, librarians are required to be good at providing services as desired by users and have broad insight.

\section{THEORETICAL STUDY}

Interpersonal communication, in general, is communication between people face to face, each person involved in the communication influences the perception of the other person's communication. ${ }^{1}$

According to Yaumi, interpersonal intelligence is different from intellectual intelligence. Frequently, intellectually intelligent people have low interpersonal communication skills. ${ }^{2}$

According to Rivai, there are five laws of communication that are essential foundations that must be built so that communication can run effectively: namely Respect, Empathy, Audible, Clarity, and Humble. ${ }^{3}$ Respect. One way to create effective communication is respect for each other who is the target of the message we convey. Respect or mutual respect is the first law in communicating with others. ${ }^{4}$ Empathy is characterized as feeling what others feel without losing one's own identity. Librarians can communicate empathy verbally and non-verbally. Non-verbally, Librarian can share empathy by showing; active involvement through appropriate facial expressions and gestures; intentional focus includes (eye contact, attentive posture, and physical proximity). ${ }^{5}$ Audible means can be heard or can be understood well. Empathy is the ability to listen first or be able to receive feedback well, while audible means that the recipient can receive the message we convey. ${ }^{6}$ Clarity (openness). An open attitude is very influential in growing effective interpersonal communication. ${ }^{7}$ If the message conveyed can be understood well, then the next thing is the clarity of the message itself, not to cause different interpretations. The fifth law of building effective relationships is humility. This attitude is an element related to the first law in creating a sense of respect for others, usually based on a humble attitude that must be possessed.

Quality is a defined process to assess the results of an activity. Quality is also defined as a service with features that satisfy users by doing something big from the start of the service needed. This is based on three characteristics, namely: Customer-oriented, preventive action-oriented, and active participation led by top management. ${ }^{8}$

The most important thing in improving the quality of services is how public service providers have the willingness and ability to be proactive in facing challenges in

\footnotetext{
${ }^{1}$ Sapril, Komunikasi Interpersonal Pustakawan, Iqra', Vol. 05 No (2011). P. 7.

2 Muhammad Yaumi, Pembelajaran Berbasis Kecerdasan Jamak: Mengidentifikasi Dan Mengembangkan Multitalenta Anak, Cet. 2 (Jakarta: Kencana).

3 Veithzal Rivai, Islamic Leadership: Membangun Super Leadership Melalui Kecerdasan Spiritual, ed. by Fatna, Ed. 1 (Jakarta: Bumi Aksara, 2013).

${ }^{4}$ Dale Carnagie, How to Win Friends and Influence People (Inggris: Simon \& Schuster, 1936).

${ }^{5}$ Hildayani Raudah, Komunikasi Interpersonal Pustakawan Dan Pemustaka Di Perpustakaan Universitas Islam Negeri SUmatra Utara Medan, Jurnal Liberary, V01.6. No. (2018).

${ }^{6}$ Rivai. Islamic Leadership : Membangun Super Leadership Melalui Kecerdasan Spiritual. p. 445

${ }^{7}$ Sapril. Komunikasi Interpersonal Pustakawan. p. 9.

${ }^{8}$ Andi Ibrahim, Konsep Dasar Manajemen Perpustakaan Dalam Mewujudkan Mutu Layanan Prima Dengan Sistem Temu Kembali Informasi Berbasis DigitaL, Desember, 2014. p. 129-138.
} 
Fitriani, Iskandar, Muhammad Yaumi,

La Ode Ismail Ahmad, Andi Ibrahim

seeing new opportunities, not being fixated on routine activities, and having flexible competencies to provide the best quality service.

Seeing this reality, the researcher is interested in further studying librarians' interpersonal communication in improving service quality in the Sheikh Yusuf library at UIN Alauddin Makassar in the circulation section. Which the center of library activities is in this section as the first to deal directly with users. And if there is good communication between the user and the Librarian, the quality of service delivery can also be in line with the operational standards that the library has determined. It's just what the Librarian expects to implement these standards consistently so that the library can be more focused and run well.

\section{RESEARCH METHODS}

The type of research used is descriptive research. Descriptive research involves describing the characteristics of a particular individual, situation, symptom, or group as it is. ${ }^{9}$ This problem is discussed through field studies. The data are obtained through semistructured interviews, observation, documentation, and other supporting instruments. All data were analyzed through methodological, phenomenological, and scientific approaches, using reduction analysis, data presentation, and drawing conclusions.

\section{IV.FINDINGS AND DISCUSSIONS}

Developing a good relationship in a library, of course, requires good communication, and in creating effective communication, a librarian must be able to be respectful, have empathy, be audible by using sentences that are easy to understand, have clarity and be humble.

Respect. It can be concluded that the library staff when they see a user entering the library in general have not applied good interpersonal communication skills, in other words the Librarian has not been able to be friendly and get used to greeting, giving a smile or other sign language that can make the user feel welcome and appreciated when he comes to the library. This seems simple, but if we apply it in the library, it will be very influential in the process of building good relations with visitors who come to seek information - so many disappointments and complaints from users that the researchers found during interviews. Most of them said that every time they visited the library, the library staff rarely greeted them and were only busy with their respective activities. This phenomenon could happen if a library lacks experts or professionals in their fields in the library.

Audible (can be heard). From some of the statements above, it can be concluded that the Librarian has tried to help provide information to every library visitor who comes looking for information. However, in general, the interviewees stated the same thing to the researcher about not knowing how to use OPAC in the library. In this case, every new admission of UIN Alauddin Makassar, Syekh Yussuf library should hold a user education that explains some related to the rules in the library. Such as the use of OPAC to make it easier to get information, the maximum limit for borrowing books and how long it can take books that can be borrowed and so on. This activity can also be a way for all librarians and library staff to get to know each other with people who will always visit the library.

9 Saat Sulaiman, Pengantar Metodologi Penelitian: Panduan Bagi Peneliti Pemula (Gowa: Pustaka Almaida, 2019). p. 127. 
Clarity (openness) in this concept concluded that the Librarian in providing services with an attitude of openness had been applied. The three informants interviewed have similarities in terms of openness to establish togetherness and cohesiveness in interpreting the concept of openness. Librarians stated that they are always open and transparent in communicating anything with the users. On the other side, the users said that the openness of the librarians was quite professional because even though some of the officers were not equipped with special knowledge in the field of libraries, every user's questions were answered properly.

Suppose the Librarian maintains good relations with the users through intensive communication with a relaxed atmosphere, transparency, sharing, listening, and understanding. In that case, the communication openness is well established. On the other hand, if the Librarian cannot maintain continuity of communication with the users, the openness in communication will not be established perfectly.

Humble. The fifth law of building effective communication is humility. This attitude is related to the first law, which is about to build a sense of respect. It is usually associated with our humble attitude.

The results of the interview stated that the Librarian's humble attitude in serving users in the library had not been fully implemented. From the answers of users, there were two different versions. Some users say that the librarians have implemented it by seeing the staff's humble, friendly, and not arrogant staff. However, some users stated that the Librarian is not humble. They show some attitudes such as not smiling, not being friendly and not greeting when doing service because there are factors that affect the Librarian. The concept of humility is influenced by time or mood, such as fatigue in doing his job.

It can be understood that librarians and staff need to be more consistent, especially when giving warnings to users. For example, warn the users not to sit in the corridor. When someone started sitting or gathering, the Librarian should warn them immediately that it is prohibited and have notified from a sticker on the wall, not when many visitors are already seated in the corridor. Remind them to pay more attention to the prohibition signs that the library made for mutual comfort.

\section{CONCLUSION}

Based on the analysis results related to librarians' interpersonal communication in building good relationships with users in the library of Sheikh Yusuf UIN Alauddin Makassar, according to field findings, it is shown that interpersonal communication of librarians in serving users is quite good. However, the attitude of respect, empathy, audible, clarity, and humble shown by the Librarian towards the users is still less prominent and does not have clear standards. Thus librarians become less proactive in serving users. 


\section{REFFERENCE}

Dale Carnagie, How to Win Friends and Influence People (Inggris: Simon \& Schuster, 1936)

Hildayani Raudah, Komunikasi Interpersonal Pustakawan Dan Pemustaka Di

Perpustakaan Universitas Islam Negeri SUmatra Utara Medan, Jurnal

Liberary, V01.6. No. (2018)

Ibrahim, Andi, Konsep Dasar Manajemen Perpustakaan Dalam Mewujudkan Mutu Layanan Prima Dengan Sistem Temu Kembali Informasi Berbasis Digital, Desember, 2014

Rivai, Veithzal, Islamic Leadership : Membangun Super Leadership Melalui Kecerdasan Spiritual, ed. by Fatna, Ed. 1 (Jakarta: Bumi Aksara, 2013)

Sapril, Komunikasi Interpersonal Pustakawan, Iqra', Vol. 05 No (2011)

Sulaiman, Saat, Pengantar Metodologi Penelitian: Panduan Bagi Peneliti Pemula (Gowa: Pustaka Almaida, 2019)

Yaumi, Muhammad, Pembelajaran Berbasis Kecerdasan Jamak: Mengidentifikasi Dan Mengembangkan Multitalenta Anak, Cet. 2 (Jakarta: Kencana)

Dale Carnagie, How to Win Friends and Influence People (Inggris: Simon \& Schuster, 1936)

Hildayani Raudah, Komunikasi Interpersonal Pustakawan Dan Pemustaka Di Perpustakaan Universitas Islam Negeri SUmatra Utara Medan, Jurnal Liberary, V01.6. No. (2018)

Ibrahim, Andi, Konsep Dasar Manajemen Perpustakaan Dalam Mewujudkan Mutu Layanan Prima Dengan Sistem Temu Kembali Informasi Berbasis Digital, Desember, 2014

Rivai, Veithzal, Islamic Leadership : Membangun Super Leadership Melalui Kecerdasan Spiritual, ed. by Fatna, Ed. 1 (Jakarta: Bumi Aksara, 2013)

Sapril, Komunikasi Interpersonal Pustakawan, Iqra', Vol. 05 No (2011)

Sulaiman, Saat, Pengantar Metodologi Penelitian: Panduan Bagi Peneliti Pemula (Gowa: Pustaka Almaida, 2019)

Yaumi, Muhammad, Pembelajaran Berbasis Kecerdasan Jamak : Mengidentifikasi Dan Mengembangkan Multitalenta Anak, Cet. 2 (Jakarta: Kencana) 